REVISTA DE DERECHO UNED, NÚM. 22, 2018

\title{
LA ADOPCIÓN ABIERTA. MEDIDAS PARA FOMENTAR SU IMPLANTACIÓN
}

\author{
OPEN ADOPTION. MEASURES TO ENCOURAGE ITS \\ IMPLEMENTATION
}

Dr. Alberto Serrano Molina

Prof. Propio Adjunto de la Universidad Pontificia Comillas de Madrid

Resumen: Han transcurrido más de dos años desde la entrada en vigor de la Ley 26/2015, de 28 de julio, de Protección a la Infancia y a la Adolescencia. Como manifestación del principio del interés superior del menor, las instituciones, tanto públicas como privadas, deben priorizar al adoptar medidas y actuaciones dirigidas a su protección, el que su vida y desarrollo tenga lugar en un entorno familiar adecuado, preferentemente (es decir, siempre que sea posible y positivo para él) en su familia de origen, así como preservar el mantenimiento de las relaciones con ella.

La adopción abierta se ha incorporado a nuestro ordenamiento jurídico para contribuir a este propósito.

Nuestro legislador pretende que ciertos menores, especialmente los más mayores, alcancen a través de la adopción abierta, una mayor estabilidad familiar y personal y que su adopción presente menos dificultades.

El objeto del presente estudio es, de una parte, conocer cuál es la implantación real de esta modalidad de adopción en nuestro país o, quizá debiéramos decir más correctamente, en las distintas Comunidades Autónomas. Ellas son las competentes por razón de la materia para su puesta en marcha. De otra, proponer algunas medidas (relacionadas con los requisitos, el procedimiento de 
constitución y efectos de la adopción abierta), para impulsar su implantación ${ }^{1}$.

Abstract: More than two years have passed since the entry into force of Law 26/2015, of July 28, on the Protection of Children and Adolescents. As a manifestation of the principle of the best interests of the child, institutions, both public and private, must prioritize that their life and development takes place in a suitable family environment, preferably in his family of origin (if it is possible and positive for him).

To this purpose, open adoption has been incorporated into our legal system.

Our legislator intends that certain minors, especially the older ones, achieve through greater open adoption, greater family and personal stability. This type of adoption presents fewer difficulties.

The object of the present study is, firstly, to know what is the actual implementation of this method of adoption in our country or, perhaps we should say more correctly, in the different Autonomous Communities. They are competent by reason of the subject for their start-up. On the other hand, it proposes some measures (related to the requirements, the constitution procedure and effects of open adoption), to promote its implementation.

Palabras clave: Adopción abierta. Comunidades Autónomas. Idoneidad de los adoptantes. Familia adoptiva. Relaciones post adoptivas

Keywords: Open adoption. Autonomous communities. suitability adopters. adoptive family. post adoption contact

Recepción original: 05/12/2017

Aceptación original: 22/01/2018

Sumario: 1. Introducción. 2. Medidas en relación con sus presupuestos o requisitos. 3. Medidas en relación con el procedimiento de constitución. 4. Medidas en relación con sus efectos. 5. Conclusiones

\footnotetext{
${ }^{1}$ El presente trabajo se realiza en el marco del proyecto de investigación «La apertura de la comunicación sobre adopción en España: en camino hacia la adopción abierta» y por la Universidad Pontificia Comillas CEIR ARISTOS Campus Mundus en el marco del proyecto de investigación «Desafíos actuales de la adopción en España: Necesidades y derechos de los menores en acogimientos y adopción».
} 


\section{INTRODUCCIÓN}

«... El Código Civil, influido por las tendencias entonces dominantes, concibió la adopción con perfiles y efectos muy estrechos. Situó a los adoptados entre dos círculos parentales, sin adscripción clara a ninguno de ellos. Esta insuficiencia de la hasta ahora vigente ordenación legal, se muestra más acusada ante la muy frecuente adopción de expósitos, donde al fallar los vínculos afectivos propios de la generación, se acrecientan los derivados de la convivencia entre adoptante y adoptado siempre expuestos al riesgo de que la familia natural, invocando pretendidos derechos cuyos deberes correlativos no afrontó, rompa los afectos nacidos de la adopción y arranque al adoptado del ambiente familiar y social en que se formó.... El arreglo de los intereses contrapuestos, que existen entre los parientes naturales, con los que el adoptado está unido por vínculos de sangre, y la nueva familia adoptiva, constituye la dificultad mayor con que la reglamentación legal de la adopción tropieza. La solución que se da en el caso de la adopción plena es, sin duda radical, pero no podía ser de otro modo si se quiere cortar de raiz el temor de interferencias abusivas de la familia natural en el círculo de la familia adoptiva...»

Las que acabamos de transcribir son las palabras con las que nuestro legislador anunciaba la reforma de la adopción dentro de la Exposición de motivos de la Ley de 24 de abril de $1958^{2}$. Una modificación necesaria de su regulación en el Código civil porque, como él explicaba, esta particular institución de protección de menores estaba adquiriendo por entonces una pujante vitalidad.

Cuando apenas quedan unos meses para que se cumpla el sesenta aniversario de su entrada en vigor, nuestro ordenamiento jurídico se ha visto envuelto recientemente en otra importante, y no menos extensa, modificación del Código civil que ha incidido en todo el sistema de protección a la infancia y a la adolescencia y, también, a la adopción pero hacia una dirección bastante diferente a la emprendida entonces.

A partir de la Convención de Naciones Unidas sobre los Derechos del Niño de 20 de noviembre de 1989, el mayor reconocimiento social y jurídico de los menores de edad como sujetos de derecho, y el principio general de que, en todas las situaciones en las que se encuentren, su interés debe ser valorado y considerado como primordial, ha traído como consecuencia —en lo que incumbe al presente trabajo-

${ }^{2}$ Ley de 24 de abril de 1958 por la que se modifican determinados artículos del Código civil (BOE núm. 99 de 25 de abril de 1958).

(C) UNED. Revista de Derecho UNED, núm. 22, 2018 
el que se considere interés superior del menor el que su vida y desarrollo tengan lugar en un entorno familiar adecuado, preferentemente (es decir, siempre que sea posible y positivo para él) en su familia de origen.

En definitiva de lo que se trata es de que alcance toda su significación el derecho que tiene reconocido toda persona adoptada a conocer sus orígenes. El final de su búsqueda no puede quedar limitado al ámbito meramente biológico (vínculo genético con sus ascendientes) o socio-familiar (el conocimiento de su historia personal-familiar) sino que debe ir más allá y, además, prolongarse en el tiempo junto a aquellos que siempre constituirán su familia de origen. Como señala SABATER BAYLE, lo que realmente beneficia a las personas adoptadas es «... contar con alguna forma de continuidad que les permita integrar el pasado con el presente y obviamente con el futuro, más que mantener las relaciones con la familia biológica de la misma manera en que anteriormente se habían desarrollado» ${ }^{3}$. Sin embargo, no debemos olvidar que será también aquí cuando puedan plantearse conflictos de interés, fundamentalmente, entre la familia biológica y la familia adoptante e indicamos biológica porque, a nuestro juicio, más infrecuente será el conflicto entre distintas familias adoptantes cuyos hijos adoptados proceden de una misma familia de origen (esto es, hermanos biológicos).

La cuestión que entonces debemos resolver es cómo conciliar este interés del menor con una institución, como la adopción, en torno a la que sobrevuela - especialmente entre los futuros adoptantes- el temor de interferencias abusivas de la familia natural.

Las diversas instituciones jurídicas competentes en esta materia han de adoptar medidas, llevar a cabo actuaciones que prioricen este objetivo así como, a lo largo de la vida del menor, preservar el mantenimiento de sus relaciones familiares (vid. artículo 2.2.c) LOPJM$^{4}$ ). Pero ¿cuáles han de ser?

Presupuesto que el objetivo principal no debe ser la ampliación de adopciones, pues siempre ha de ser entendida como una medida subsidiaria, la opción de nuestro de nuestro legislador estatal $-\mathrm{y}$ desde hace ya varios años de algunos autonómicos- se ha traduci-

${ }^{3}$ SABATER BAYLE, E. «la adopción abierta en el derecho español» en Actualidad Jurídica Iberoamericana, ISSN 2386-4567, IDIBE, núm. 4 ter, julio 2016, pág. 85.

${ }^{4}$ Ley Orgánica 1/1996, de 15 de enero, de Protección Jurídica del Menor, de modificación parcial del Código Civil y de la Ley de Enjuiciamiento Civil, modificada por Ley Orgánica 8/2015, de 22 de julio, de modificación del sistema de protección a la infancia y a la adolescencia (BOE 23 de julio de 2015). 
do en una apuesta por admitir la posibilidad, cuando el interés del adoptado así lo aconseje (en razón de su situación familiar, edad o cualquier otra circunstancia significativa) de que se pueda mantener alguna forma de relación o contacto a través de visitas o comunicaciones entre el menor, los miembros de la familia de origen que se considere oportuno y los adoptantes, incluida su propia familia (vid. artículo $\left.178.4 .^{\circ} \mathrm{CC}\right)$.

Se trata de lo que se ha venido en llamar, la adopción abierta ${ }^{5}$.

A juicio de CÉCILE JEANNIN ${ }^{6}$, podrían escribirse páginas y páginas sobre el concepto de adopción abierta, dadas todas las prácticas formales e informales a las cuales se refiere. A su juicio, este tipo de adopción se caracteriza «... por el mantenimiento de una cierta forma de contacto entre el niño, los miembros de su familia de origen y la familia adoptiva. La naturaleza en sí del contacto puede variar, desde un simple intercambio de información no reveladora de la identidad de las personas involucradas - adopciones llamadas, por algunos, semi-abiertas - hasta una forma de contacto directo - adopciones llamadas, por algunos, totalmente abiertas-.»

Y, en el mismo sentido, ANGUITA RÍOS advierte que tras la expresión "adopción abierta» se contemplan otras hipótesis más amplias: «En atención a los distintos países donde se admite podemos considerar que hay distintas formas de entender la adopción abierta. La concepción más amplia sería aquella en donde los padres biológicos tienen cierto control con respecto a la identidad de los padres adoptivos, y pueden elegir después de investigar las biografías proporcionadas por la agencia pudiendo optar por conocerse y permanecer en contacto durante el embarazo, llegando incluso los padres adoptivos a presenciar el nacimiento de su hijo. Esta concepción no es la seguida por el legislador español quien mantiene el régimen jurídico establecido en las reformas anteriores caracterizado por una clara intervención administrativa».

En cuanto al empleo de dicha denominación por nuestro legislador estatal, en la Exposición de motivos de la Ley 26/2015 de 28 de julio, de modificación del sistema de protección a la infancia y a la

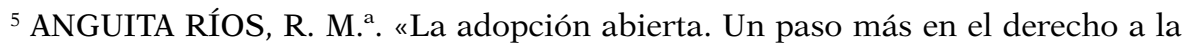
identidad biológica del adoptado», Revista Doctrinal Aranzadi Civil-Mercantil, núm. 11/2016. Parte Doctrina. Editorial Aranzadi, S.A.U., Cizur Menor, 2016 (BIB 2016/85672). Fecha de la última consulta 15 de noviembre de 2017.

${ }^{6}$ El nuevo régimen jurídico del menor. La reforma legislativa de 2015 (Directora Mayor del Hoyo, M. ${ }^{\mathrm{a}}$. V.) Thomson Reuters Aranzadi, Pamplona, 2017, pág. 388.

(C) UNED. Revista de Derecho UNED, núm. 22, 2018 
adolescencia $^{7}$ dice así: «... En el artículo 178 se incluye, como una importante novedad, la posibilidad de que, a pesar de que al constituirse la adopción se extingan los vínculos jurídicos entre el adoptado y su familia de procedencia, pueda mantenerse con algún miembro de ella alguna forma de relación o contacto a través de visitas o de comunicaciones, lo que podría denominarse como adopción abierta...».

Junto a esta motivación teórica — permítasenos la expresión-que ha impulsado la introducción de la adopción abierta en nuestro Ordenamiento jurídico amparada en el principio de considerar más acorde con el interés del menor el mantenimiento de contactos con su familia de origen, se esconde otra que podemos calificar como más "práctica». El propio legislador se hace eco de la misma en la Exposición de motivos de la citada Ley 26/2015: «... La oportunidad de introducir esta figura en nuestro ordenamiento jurídico obedece a la búsqueda de alternativas consensuadas, familiares y permanentes que permitan dotar de estabilidad familiar a algunos menores, especialmente los más mayores, cuya adopción presenta más dificultades. A través de la adopción abierta, se flexibiliza la institución de la adopción, posibilitando que la familia de origen acepte mejor la "pérdida», y que el menor pueda beneficiarse de una vida estable en su familia adoptante, manteniendo vínculos con la familia de la que proviene, en especial con sus hermanos, y con la que, en muchos casos, ha mantenido relación durante el acogimiento ${ }^{8}$, relación que aunque no estuviera formalizada continúa por la vía de hecho.»

Dicho con otras palabras, se quiere ver en la adopción abierta la vía para resolver en nuestro país el problema que existe con una serie de menores cuya adopción presenta mayores dificultades en la práctica.

${ }^{7}$ Ley 26/2015, de 28 de julio, de modificación del sistema de protección a la infancia y a la adolescencia (BOE 29 julio de 2015) El CGPJ también nos ofrece una definición de la misma: «... Se refiere a aquella adopción en que los padres biológicos y los padres adoptivos se conocen, comparten sus identidades, intercambian información y pueden comunicarse a lo largo de los años, manteniendo el adoptado relación con su familia de origen y, especialmente, con sus hermanos biológicos» Vid. Informe al Anteproyecto de Ley de Protección a la Infancia de 30 de septiembre de 2014 en www.poderjudicial.es (fecha de la última consulta: 15 de noviembre de 2017), pág. 85.

${ }^{8}$ En este sentido se manifestó D. Pere Amorós Martí Comparecencia del Catedrático de Pedagogía de la Universidad de Barcelona, durante su comparecencia ante la Comisión especial del Senado donde propuso la ampliación de la adopción nacional, con la modalidad de la adopción abierta, ya que «... que podría resolver muchas situaciones de menores que actualmente están en una situación temporal de acogimiento permanente y podrían pasar a una situación definitiva por medio de esta fórmula (vid. BOCG. Senado IX Legislatura. Boletín General. Serie I. núm. 545 de 17 de noviembre de 2010) pág. 28. 
A este respecto, MÚGICA FLORES, durante su comparecencia ante la Comisión especial del Senado, ${ }^{9}$ manifestó que había que crear puentes entre el acogimiento y la adopción. Muchos acogimientos permanentes - decía- deberían ser ya adopciones que es como crecen las adopciones nacionales en la mayor parte de los países europeos. Para muchos técnicos, explicaba, si un niño acogido durante cinco años tiene que ser adoptado porque para sus padres ya no hay probabilidad de recuperación, lo más idóneo es optar por acogimientos permanentes, porque si no tendrían que sacar a ese niño que lleva cinco años en la familia de acogida, y llevarlo a una familia adoptiva, es decir, volver a abandonarlo para poder adoptarlo. El adoptante preferente tendría que ser el acogedor; por delante de cualquier otro.

¿Y cómo proceder ante esta situación? MÚGICA FLORES, además de proponer la búsqueda de nuevas modalidades de acogimiento familiar, apostaba por la adopción abierta entendida como aquélla «en la cual los niños adoptados mantienen relación con sus orígenes, que pueden ser hermanos, abuelos, tíos o personas de su entorno, incluso también con sus propios padres biológicos, pero es el adoptante el que ejerce los derechos de la patria potestad, con lo cual tiene el poder suficiente para gestionar adecuadamente la situación y, a la vez, el niño mantiene los orígenes cercanos porque son los que mejor le van a permitir entender por qué tuvo que salir de aquella familia. Muchos acogimientos permanentes en España no son acogimientos, son adopciones abiertas, en las que además las personas que ejercen el rol más importante, que es el de criar a los niños, con frecuencia son las que menos poder tienen en todo el sistema.»

También la opción de la novedosa adopción abierta está empezando a ser tomada en consideración por nuestros tribunales. Sirvan de ejemplo los siguientes razonamientos expuestos en la sentencia de la Audiencia Provincial de Soria de 15 de diciembre de $2016^{10}$ : «Tanta es la importancia que se le da al mantenimiento de las relaciones con la familia de origen, especialmente la relación con hermanos biológicos, si se considera beneficioso para el menor, que en la actualidad y tras la reforma operada en el Código civil por la Ley 26/2015 de modifica-

${ }^{9}$ D. Javier Múgica Flores es Psicólogo y terapeuta familiar, técnico especializado en acogimiento y adopción en el servicio Arlobi-adoptia de Agintzari, Sociedad Cooperativa de Iniciativa Social (vid. BOCG. Senado IX Legislatura. Boletín General. Serie I. núm. 545 cit.), pág. 29.

${ }^{10}$ El Derecho. Base de Datos (EDJ 2016/292713) AP Soria, Sec. 1. a , S. 15/12/2016, n. ${ }^{\circ} 145 / 2016$, rec. 166/2016, Fundamento Jurídico cuarto (fecha de la última consulta 15 noviembre 2017). 
ción del sistema de protección a la infancia y a la adolescencia, se ha introducido una importante novedad en la institución de la adopción, y que conviene mencionar en este litigio, por ser una realidad a la que se va a enfrentar la Administración en breve...»

Y añade más adelante: «... Todo lo expuesto pone de manifiesto lo difícil que resulta resolver situaciones como la que ahora se nos presenta, en los que debe decidirse sobre los efectos de los derechos más genuinamente personales. A los que hay que añadir que se debe decidir sobre situaciones que evolucionan con el tiempo. Es decir se decide sobre la órbita de derecho y relaciones de una persona que en la actualidad tiene 9 años, pero que en breve, con la entrada en la adolescencia, empezará a ser consciente de su propia situación y de su origen; y que empezará a hacerse las preguntas que se hacen todos los adolescentes, cuestionamientos que se hacen mucho más complicados en adolescentes que proceden de una adopción. La resolución que ahora se dicta ha de valorarse como el diagnóstico que se hace en un concreto momento, como una foto fija. Pero hemos de ser conscientes de que el tiempo transcurre, que las personas evolucionan, y que las instituciones de protección de menores deben dar respuesta a estas necesidades que van apareciendo. Dicho en términos más explícitos: es posible que la menor de 9 años en el momento actual nada se pregunte sobre su origen, procedencia y lazos familiares, pero es muy posible, que estas inquietudes aparezcan en unos años, y que si no son convenientemente tratadas, se empiece a fantasear sobre ellas, $\mathrm{u}$ dar lugar a respuestas inadecuadas. Por ello, las instituciones de protección de menores deben dar las respuestas que en cada momento precise el menor, y la legislación, proporcionar instrumentos para dar respuestas a estas situaciones.»

Pues bien, han transcurrido ya más de dos años desde la entrada en vigor de la Ley 26/2015, y la pregunta que debemos plantearnos gira sobre el establecimiento real de la adopción abierta en nuestro país o, quizá debiéramos decir más correctamente, en las distintas Comunidades Autónomas pues son ellas las competentes por razón de la materia (en la mayoría de los supuestos en los que se puede plantear) para su puesta en marcha.

Para responder a este interrogante, nos vamos a servir del estudio de las contestaciones que los distintos responsables de nuestras Comunidades Autónomas ofrecieron a un cuestionario en torno a la instauración en sus territorios de la adopción abierta (en adelante E.CCAA). Las mismas fueron expuestas durante los días 21 y 22 de junio en unas jornadas que con el título «Rompiendo moldes: adopciones especiales y adopciones abiertas en pro del interés superior 
del niño» se desarrollaron en la Universidad Pontificia Comillas de Madrid $^{11}$.

Antes de comenzar con la presentación de algunas de las conclusiones del Estudio mencionado, no queremos dejar de hacer mención sobre un aspecto que suele pasar desapercibido. Ha sido frecuente calificar como de "gran novedad» la incorporación de la adopción abierta en nuestro país cuando la verdad es que en varias de nuestras Comunidades Autónomas ya se estaban dando supuestos de esta modalidad de adopción antes de la entrada en vigor de la Ley.

No resulta difícil demostrar esta afirmación. En efecto, sin ir más lejos, PALACIOS GONZÁLEZ ${ }^{12}$ ya concretó algunas hipótesis durante su comparecencia en la Comisión del Senado: «En España hacemos adopción abierta cuando por alguna razón dos, tres o cuatro hermanos deben ser separados. Permitimos que esos hermanos que están adoptados, por ejemplo, en familias distintas, se vean entre sí. Eso es una forma de adopción abierta. Una adopción abierta es, por ejemplo, cuando a un niño que ha sido adoptado mayor, después de haber vivido muchos años con sus abuelos con los que mantiene buenas relaciones, los adoptantes le permiten que mantenga el contacto con sus abuelos biológicos. Lo que no tenemos aquí es la fórmula más extrema de adopción abierta, que es cuando el contacto se da entre los padres biológicos y los padres adoptivos o entre el niño y sus padres adoptivos. Eso para algunos casos concretos puede ser una buena solución...».

Pero es que basta leer el artículo 9 del Decreto 282/2002, de 12 de noviembre que regula el Acogimiento Familiar y Adopción en la Comunidad Autónoma de Andalucía ${ }^{13}$ o el artículo 6 del Decreto

${ }^{11}$ Esta actividad de desarrolló y ha sido parcialmente financiada por el Ministerio de Economía y Competitividad en el marco del proyecto de investigación «La apertura de la comunicación sobre adopción en España: en camino hacia la adopción abierta» y por la Universidad Pontificia Comillas CEIR ARISTOS Campus Mundus en el marco del proyecto de investigación «Desafíos actuales de la adopción en España: Necesidades y derechos de los menores en acogimientos y adopción».

${ }^{12}$ D. Jesús Palacios González es Catedrático de Psicología Evolutiva y de la Educación de la Fac. de Psicología de la Universidad de Sevilla, (vid. BOCG. Senado IX Legislatura. Boletín General. Serie I. núm. 545 de 17 de noviembre de 2010, pág. 27.

${ }^{13}$ Artículo 9: 1. Los menores tendrán derecho a conservar los vínculos afectivos con sus hermanos y, a tal fin, la Administración de la Junta de Andalucía procurará que todos ellos sean acogidos o adoptados por una misma persona o familia, y, en caso de separación, tratará de facilitar la relación entre los mismos. 2. Los menores acogidos tendrán derecho a mantener contacto con sus familias biológicas, directamente o a través de los diversos procedimientos de comunicación, sin que 
114/2008, de 17 de junio que regula el procedimiento de actuación que deberán seguir las Diputaciones Forales en la Comunidad Autónoma del País Vasco en materia de adopción de personas menores de edad $^{14}$ o el artículo 235-47, apartado $4^{\circ}$ del Código civil de Cataluña donde se puede leer lo siguiente: «La autoridad judicial, excepcionalmente, a propuesta de la Entidad pública competente o del Ministerio Fiscal, puede disponer que se mantengan las relaciones personales del adoptado con la familia de origen en los supuestos a que se refiere el artículo 235-44.4 (supuestos de adopción y acogimiento internacionales) o si existen vínculos afectivos cuya ruptura sea gravemente perjudicial para el interés del menor.»

Y ya, finalmente, para terminar, puede verse el artículo 74 Ley $3 / 2011$, de 30 de junio $^{15}$ de apoyo a la familia y a la convivencia en la Comunidad Autónoma de Galicia, donde también se contempla la posibilidad de mantener contactos entre hermanos biológicos. ${ }^{16}$

Dicho esto y no obstante esta realidad legislativa en nuestro país, el primer dato que llamó nuestra atención es que, desde la entrada en vigor de la Ley, sólo en seis de nuestras Comunidades Autónomas se

aquél deba ser interrumpido más que en los casos en que el equipo técnico haya constatado un grave riesgo de perjuicio físico o psíquico para los menores. La suspensión se podrá acordar con carácter cautelar previa audiencia de los menores, en su caso, y de la familia biológica, instando de forma inmediata la correspondiente resolución judicial (Boletín Oficial de la Junta de Andalucía núm. 135 de 19 de noviembre de 2002).

${ }^{14}$ Dentro de un apartado general dedicado a los derechos de las personas menores de edad en relación con la adopción prevé que las personas menores de edad tienen derecho a conservar las relaciones personales con sus hermanos y hermanas y, a tal fin, se procurará que todas ellas sean adoptadas por la misma persona o familia y, en caso de separación, se tratará de facilitar la relación entre las mismas, salvo en los casos en que se valore un grave riesgo de perjuicio en el bienestar de alguna de ellas. 2. A excepción de los casos en los que se contemple la conveniencia de la adopción conjunta de hermanos, no se podrá formular un ofrecimiento ni solicitar una declaración de idoneidad que incluya adoptar simultáneamente a varias personas menores de edad (Boletín Oficial del País Vasco núm. 122 de 27 de junio de 2008).

${ }^{15}$ Artículo 74. 1. Las personas menores de edad tendrán derecho a conservar los vínculos afectivos con sus hermanos y hermanas, y a tal fin la Administración de la Xunta de Galicia procurará que todos ellos sean acogidos o adoptados por una misma persona o familia, y, en caso de separación, tratará de facilitar la relación entre ellos y ellas (Diario Oficial de Galicia núm. 134 de 13 de julio de 2011).

${ }^{16}$ El pasado 2 de noviembre de 2017, Juan Antonio Pavón Pérez, presidente de la Asociación de Familias Adoptantes de Extremadura, anunciaba en un artículo publicado en el Periódico de Extremadura, la próxima publicación del Decreto por el que se regula la Adopción abierta en dicha Comunidad Autónoma (http://www.elperiodicoextremadura.com/noticias/opinion/adopcion-abiertaextremadura. Fecha de la última consulta: 15 de noviembre de 2017). 
había constituido alguna adopción abierta ¿Debe sorprendernos este dato? A nuestro juicio, no.

De una parte, es cierto que nuestro legislador, en la Exposición de motivos de la Ley 26/2015 declaraba que esta modalidad de adopción se encontraba establecida con diferente amplitud y contenido en la legislación de diversos países (tales como los Estados Unidos de América ${ }^{17}$, Gran Bretaña, Austria, Canadá o Nueva Zelanda). Lo que no decía, como sí puso de manifiesto PALACIOS GONZÁLEZ en la Comisión especial del Senado, es que en todos los países en que estaba admitida - la adopción abierta-, ésta, era minoritaria ${ }^{18}$. Ni tampoco, como subraya CÉCILE JEANNIN ${ }^{19}$, que esta institución jurídica "permanece totalmente excluida en un número considerable de países de origen, en particular en América Latina y Europa del Este, que han manifestado su firme oposición a este sistema... Entre las razones mencionadas se encuentran el desequilibrio socioeconómico entre las familias de origen y las familias adoptivas, los posibles conflictos de intereses entre las distintas partes involucradas, y la violación del artículo 29 del Convenio de La Haya de 1993 sobre la protección de los niños y la cooperación en materia de adopción internacional (CLH1993) cuando estos contactos se inician antes de la asignación profesional.»

Es más, concretamente, con respecto a EE.UU que siempre parece el modelo a seguir, MARTÍNEZ DE AGUIRRE ALDAZ ${ }^{20}$ señala lo siguiente: «La adopción abierta ha surgido, y se ha consolidado, en un marco legal y sociológico muy diferente al nuestro: en concreto, básicamente en Estados Unidos, que tiene un sistema de adopción como acto privado, con una intervención pública muy limitada, en el que el protagonismo básico lo tienen las voluntades respectivas de adoptantes y padres biológicos: es el acuerdo entre ambos el que genera la adopción, y por tanto es habitual el contacto inicial entre unos y otros (típicamente, entre la madre gestante y los futuros adoptantes, lo que en muchas ocasiones incluye, por ejemplo, el abono a la madres de los gastos de embarazo y parto): en ese contexto, la adopción abierta

${ }^{17}$ Actualmente, indica Vázquez-Pastor, «en Estados Unidos la mayor parte de las adopciones son abiertas; de hecho, como destaca el Independent Adoption Center, la adopción abierta (open adoption) se ha convertido en la regla general en adopción de menores, frente a la adopción cerrada, que ha pasado a ser excepcional en dicho país.» (VÁZQUEZ-PASTOR JIMÉNEZ, L. «La nueva figura de la adopción abierta en el ordenamiento jurídico español» en Actualidad civil, núm. 4, abril de 2017, pág. 11.

${ }^{18}$ Vid. nota núm. 12.

${ }^{19}$ El nuevo régimen jurídico del menor. La reforma legislativa de 2015, cit., pág. 389.

${ }^{20}$ El nuevo régimen jurídico del menor. La reforma legislativa de 2015, cit., pág. 348. 
se presenta como una derivación lógica y no conflictiva del sistema, en el que encaja pacíficamente. No es el caso del sistema español...»

El escaso número actual de adopciones abiertas, sin duda, tiene su explicación en una diversidad de motivos. En primer lugar, de la información obtenida del E.CCAA, en mi opinión personal, no hay que descartar la falta de recursos suficientes, materiales y humanos dirigidos hacia su establecimiento. En efecto, no cabe duda de que desde las Comunidades Autónomas se está llevando a cabo un gran esfuerzo en orden a su implantación pero también hay que hacer hincapié en que aún queda un largo camino por recorrer. Así, por ejemplo, en la mayoría de ellas sí que se han actualizado los contenidos de las charlas y sesiones informativas que se imparten tanto a los posibles adoptantes como a las familias que tienen en acogida a algún menor pero, también, en más de la mitad de ellas todavía no se han terminado de adaptar los folletos informativos o las páginas Webs ni tampoco se han adaptado los cursos de formación teniendo en cuenta la posibilidad de la adopción abierta ni los modelos de ofrecimiento para la adopción.

Junto a este motivo y en segundo lugar, no hay que olvidar la causa, a nuestro juicio, más importante, la que impide en la mayoría de los casos que la maquinaria de la Comunidad Autónoma o de la Fiscalía, se ponga en marcha. La desconfianza.

En efecto, hace falta el «sí quiero» de las familias biológica y adoptiva así como del menor adoptando.

DE LA ROSA CORTINA nos recuerda que en ya en los trabajos preparatorios del Anteproyecto de 2011 se decía que «... no todos los adoptantes potenciales están dispuestos a pagar un precio que ellos consideran tan alto para obtener un niño. Quieren tener la misma autonomía y la misma privacidad que el resto de los padres, y no se simples guardianes de un niño del que su destino será decidido finalmente por sus padres biológicos. La mayoría aceptarían una postura más abierta si ello significa obtener información más amplia sobre el pasado familiar y médico del niño pero aceptan mal la idea de compartir la autoridad parental. Por ello, se inclinan más por métodos de procreación asistida o por la adopción internacional, que les asegura que la familia de origen no va a reivindicar derechos sobre el niño» ${ }^{21}$.

${ }^{21}$ DE LA ROSA CORTINA, J.M. Materiales para interpretar la reforma en la legislación sobre protección jurídica del menor https://www.fiscal.es/fiscal/PA_ WebApp (fecha última consulta: 15 noviembre 2017). 
Asimismo, ADROHER BIOSCA, por entonces Directora General de Familia e Infancia del Ministerio de Sanidad, aseguraba en un artículo publicado en el diario El País que muchas familias de origen, «no permiten la adopción porque no quieren perder los vínculos, y esa es una de las razones por las que muchos niños acaban viviendo durante años en centros de protección o en familias de acogida provisionales. Con esto pretendemos esas familias de origen se atrevan a dar el salto, y también que haya muchas más que se lancen a acoger a esos niños porque, aunque estén obligadas a mantener los vínculos con los padres biológicos, no tendrán que vivir con la amenaza de que se los pueden quitar» ${ }^{22}$.

Y es que resulta unánime la recomendación de cuantos se adentran en el estudio o en la práctica de esta adopción abierta, de actuar con una gran cautela y prudencia a la hora de otorgar viabilidad a esta modalidad de adopción.

KATZ, JILL, mediadora profesional en los EE.UU., explica que cada familia y, a veces, cada miembro de la familia, puede tener una definición personal diferente de lo que sea la adopción abierta. «Debido a que los padres biológicos pueden tener un entendimiento diferente de la «adopción abierta» que los padres adoptivos, la mediación es una herramienta que puede ayudar a crear una definición de «adopción abierta» que sea comprendida y aceptada por los padres biológicos y adoptivos» ${ }^{23}$.

Y, en nuestro país, el Consejo General del Poder Judicial en su Informe al Anteproyecto de Ley de Protección a la Infancia ${ }^{24}$, se expresaba en esos términos: «... No existe un consenso sobre la idoneidad de esta clase de adopción, que cuenta con defensores y detractores. La posibilidad de la misma se propuso por algunos de los expertos que comparecieron ante la Comisión especial del Senado de estudio de la problemática de la adopción nacional y otros temas afines, si bien no fue recogida en las conclusiones del informe ni en el Anteproyecto de la Ley de Actualización sobre la Protección a la Infancia del año 2011. No se da ninguna razón de su inclusión ahora, más allá de su existencia en otros países...».

Son numerosas las aportaciones que tanto desde el ámbito jurídico como, especialmente, desde la psicología, nos transmiten una vi-

${ }^{22}$ https://politica.elpais.com/politica/2014/09/30/actualidad (fecha última consulta: 15 noviembre 2017)

${ }^{23} \mathrm{Vid}$. http://www.pediatriasocial.es/HtmlRes/Files/ISS_2015_194septiembre_ boletin_ESP.pdf. cit. pág. 8 (fecha última consulta: 15 noviembre 2017).

${ }^{24}$ Informe al Anteproyecto de Ley de Protección a la Infancia, cit. en la nota núm. siete, págs. 85 y 86 . 
sión global acerca de las ventajas y los inconvenientes de la modalidad de adopción objeto del presente estudio. Para una aproximación a la misma, seguimos a la profesora SABATER BAYLE ${ }^{25}$, quien entre los aspectos positivos destaca: a) el hecho de revelar a los niños la verdad sobre los parientes de origen contribuye a evitar futuras decepciones que podrían plantearse más adelante cuando la descubrieran b) el conocimiento por parte del niño de que los miembros de la familia de origen muestran interés y preocupación por sus progresos escolares a pesar de no convivir con él, contribuye a reforzar su autoestima y le ayuda a construir su identidad; c) el mantenimiento de contacto con los parientes de origen, que se encuentran «desaparecidos» de su entorno vital, puede contribuir a evitar que se produzcan en el menor reacciones de rechazo a establecer nuevas vinculaciones afectivas con la familia adoptante; d) También puede ayudar a los parientes de origen a resolver su aflicción por la pérdida del hijo y conseguir informaciones sobre su devenir o su nueva vida; e) resulta reconfortante para los adoptantes como padres constatar que la conflictiva cuestión del mantenimiento de contactos con la familia biológica se está abordando de manera planificada y cuenta con soporte profesional

Y entre los negativos, los siguientes:: a) El contacto directo con la familia de origen puede tener implicaciones negativas para la capacidad del niño de establecer vínculos con su nueva familia adoptiva y paralizar o dificultar sus sentimientos de pertenencia y permanencia en ella; b) En caso de que los contactos resultaran negativos para el adoptado, ello podría perjudicarle doblemente, por representar para él un segundo rechazo; pero, aun cuando resultaran positivos, siempre pueden causar tensión emocional al menor, especialmente cuando se trate de niños mayores; c) Puede llegar a ser muy difícil para los padres adoptantes el mantenimiento de una relación positiva con los familiares de origen, según fueran las circunstancias en que los niños fueron removidos de la custodia de ésta (así en los casos de haber precedido a la adopción situaciones de abandono y maltrato infantil) y d) Existe el riesgo de que las familias de origen utilicen el contacto con el niño para menoscabar la decisión de su entrega en adopción, incluso involuntariamente.

Llegados a este punto ¿Qué medidas se pueden adoptar, a nuestro juicio, para mejorar el establecimiento de la adopción abierta?

${ }^{25}$ SABATER BAYLE, E. «La adopción abierta en el derecho español» cit., págs. 83 y 84 . 
Para responder a esta pregunta, dividiremos nuestras propuestas en relación con los presupuestos o requisitos de la adopción abierta. En segundo lugar, con respecto al aspecto procedimental y, para terminar, en lo concerniente a los efectos que le son propios.

\section{MEDIDAS EN RELACIÓN CON SUS PRESUPUESTOS O REQUISITOS}

Comenzando por las personas que quieren ser adoptantes, nadie puede obviar que esta modalidad de adopción puede presentar ciertas incertidumbres, dificultades, en especial, para ellas. Quizá el legislador pudo haber exigido unos requisitos especiales de capacidad (pensemos unos requisitos de edad distintos a los previstos en la actualidad) pero no lo ha hecho. Sí, en cambio, ha exigido como única especialidad con respecto al régimen general el que en su declaración de idoneidad ha de hacerse constar expresamente si aceptarían a un menor que fuese a mantener relaciones (visitas, comunicaciones) con la familia de origen.

De acuerdo con el artículo 176, 3 CC, por idoneidad ha de entenderse «... la capacidad, aptitud y motivación adecuadas para ejercer la responsabilidad parental, atendiendo a las necesidades de los menores a adoptar, y para asumir las peculiaridades, consecuencias y responsabilidades que conlleva la adopción.

La declaración de idoneidad por la Entidad Pública requerirá una valoración psicosocial sobre la situación personal, familiar, relacional y social de los adoptantes, así como su capacidad para establecer vínculos estables y seguros, sus habilidades educativas y su aptitud para atender a un menor en función de sus singulares circunstancias.»

Llevada esta regulación al ámbito concreto de la adopción abier$\mathrm{ta}^{26}$, Ruiz-Rico Ruiz-Morón señala que «... El criterio que ha de

${ }^{26}$ Es este un requisito cuya configuración inicial en el anteproyecto ya contó con alguna dificultad puesta de manifiesto por la Fiscalía en su informe. Se decía así exactamente: "... Creemos que si finalmente esta legítima opción de política legislativa se asume, debiera no obstante suprimirse el último párrafo del precepto: en la declaración de idoneidad deberá valorarse en estos casos la disposición favorable al mantenimiento de esta relación con la familia de origen. Tal y como está redactada, parece que la disposición favorable a la adopción abierta será positivamente valorada para emitir la declaración de idoneidad. En nuestra opinión esto no sería correcto. Pueden los solicitantes ser absolutamente idóneos para adoptar y ser totalmente contrarios a las adopciones abiertas. La redacción mejoraría en nuestra opinión de la siguiente forma: en la declaración de idoneidad deberá 
guiar la decisión en cada caso, es exclusivamente el interés del menor en razón de su situación familiar, edad o cualquier otra circunstancia significativa que lo aconseje. Por esta razón, la selección previa del adoptante concreto debe estar orientada por su disposición a favor del carácter abierto de la futura adopción... No se condiciona la declaración de idoneidad a la actitud del posible adoptante hacia la adopción abierta, pero indudablemente si el interés del concreto menor aconseja el mantenimiento de relaciones con la familia de origen, no podrá ser elegido como adoptante más idóneo quien se ha manifestado en contra de tal posibilidad. Tampoco especifica el precepto las consecuencias que tendría el cambio de postura de adoptante en el tiempo que medie entre la declaración de idoneidad y la constitución de la adopción. No obstante, el mismo interés superior del menor aconsejaría en esos supuestos la negativa del Juez a la adopción.» ${ }^{27}$

Preguntadas las Comunidades Autónomas acerca de si se había procedido a adaptar el tradicional concepto de idoneidad a esta nueva modalidad de adopción, de acuerdo con la información obtenida en el E.CCAA, si bien es cierto que aún se está pendiente, en la mayoría de las ellas, de dar una nueva configuración a los materiales (formularios), sí que se está teniendo muy en cuenta a nivel individual en los procesos adoptivos. Por ejemplo, a los futuros adoptantes se les plantea si aceptarían la participación de la madre biológica o con qué miembros de la familia de origen estarían dispuestos a mantener contactos.

Es cierto que los contactos que se promueven no lo son tanto con los progenitores como con otros familiares, especialmente, los hermanos.

También hay que hacer hincapié en que la mayoría de nuestras Comunidades Autónomas ya han adaptado los estudios psicosociales

hacerse constar si los solicitantes aceptarían adoptar a un menor que fuese a mantener la relación con la familia de origen. Con esta redacción quedaría claro que cabe declarar idóneas a personas que rechazan la adopción abierta, por lo que éstas a las únicas adopciones a las que no podrían optar sería a este tipo, mientras que los declarados idóneos que admiten la adopción abierta serían candidatos no sólo para adopciones ordinarias sino también para adopciones abiertas. Informe del Consejo Fiscal al Anteproyecto de Ley de Protección a la Infancia de 11 de julio de 2014, págs. 76 y 77. En https//www.fiscal.es (fecha de la última consulta: 15 de noviembre de 2017).

${ }^{27}$ RUIZ-RICO RUIZ-MORON, J. «Últimas reformas de las instituciones privadas de protección de menores y la filiación por la Ley 26/2015, de modificación del sistema de protección a la infancia y la adolescencia» en Revista Doctrinal Aranzadi Civil-Mercantil, núm. 3/2016, parte Doctrina, Editorial Aranzadi, S.A.U., Cizur Menor, 2016 (BIB2016/862) fecha última consulta: 15 noviembre 2017. 
teniendo en cuenta la posibilidad de este tipo de adopción y que se han fijado o se encuentran en desarrollo la fijación de los criterios específicos para valorar la idoneidad de los adoptantes en estos casos.

A nuestro juicio sería oportuno, especialmente en estos momentos incipientes en los que se encuentra la adopción abierta, que entre las distintas Comunidades Autónomas se diera un mayor grado de colaboración en lo relativo al tratamiento del requisito de la idoneidad con el propósito de alcanzar un tratamiento unificado, es decir, con independencia del territorio en el que nos encontremos.

Asimismo, sería muy aconsejable la creación de registros específicos de familias solicitantes de adopciones abiertas. Constituirían un instrumento de gran utilidad a fin de permitir la adopción, incluso, por familias cuya residencia se sitúa en una Comunidad Autónoma distinta a las de aquéllos. En la actualidad, de acuerdo con los datos que refleja el E.CCAA, la inmensa mayoría de nuestras Comunidades Autónomas ni los han creado ni se encuentran en proceso de hacerlo. Teniendo en cuenta que casi el sesenta por ciento de la iniciativa de las tramitaciones de las adopciones abiertas ha correspondido a las Entidades Públicas, la constitución de dichos registros, insistimos, contribuiría a aumentar la adoptabilidad de los menores.

Dentro de este contexto dedicado a la idoneidad de las personas que quieren adoptar, DE TORRES PEREA, tras hacer hincapié en las importantes diferencias que separan la regulación española de la adopción abierta con el sistema americano, se pregunta si la familia de origen podría exigir que los padres adoptantes fueran miembros de la Iglesia a la que ellos pertenecen o de su mismo grupo racial o que mantuvieran su misma tradición cultural y lingüística "¿Se trata de un modelo a importar? ¿La identidad racial, lingüística o cultural ha de ser preservada en interés del menor? Téngase en cuenta -concluye el citado autor - que el artículo 11 de la Ley Orgánica de Protección Jurídica del menor señala que será principio rector de la actuación de los poderes públicos en relación con los menores el respeto y la valoración de la diversidad étnica y cultural» ${ }^{28}$.

En nuestra opinión, en modo alguno podría tratarse de una exigencia. Es más, con relación a determinados aspectos, tal imposición podría llegar a atentar contra determinados derechos reconocidos en nuestra Carta Magna. Cuestión distinta es que la existencia de una afinidad socio cultural allanaría posibles reticencias entre las partes involucradas en la adopción.

${ }^{28}$ DE TORRES PEREA, J.M., «Problemas actuales relacionados con la adopción» en Revista de Derecho de Familia, núm. 72 (julio-septiembre 2016), pág. 66.

(C) UNED. Revista de Derecho UNED, núm. 22, 2018 
Para terminar quisiéramos hacer una breve referencia a la consideración que nuestro legislador ha tenido para con las respectivas familias, tanto de los adoptantes como de la familia biológica.

Así es, para que el juez pueda constituir la adopción, la Ley llama a diversas personas con el fin de que intervengan en el procedimiento judicial: unas prestando su consentimiento; otras, su asentimiento y, por último, otras simplemente su opinión. El artículo $178,4^{\circ} \mathrm{CC}$ señala expresamente al respecto: «... el Juez, al constituir la adopción, podrá acordar el mantenimiento de dicha relación, determinando su periodicidad, duración y condiciones, a propuesta de la Entidad Pública o del Ministerio Fiscal y con el consentimiento de la familia adoptiva y del adoptando si tuviera suficiente madurez y siempre si fuere mayor de doce años...»

A la luz de este precepto, es claro que son precisos, de una parte, el consentimiento de la familia adoptiva, esto es, no sólo, del o los adoptantes (además del de el adoptando mayor de doce años o, menor de esa edad, pero con suficiente madurez como para prestarlo).

Como expone CALLEJO RODRÍGUEZ ${ }^{29}: » \ldots$ a diferencia del consentimiento a la adopción normal, que corresponde prestarlo al «adoptante o adoptantes» (art. 177.1 CC), en la adopción abierta el artículo 178.4.2 CC requiere el consentimiento de la «familia adoptiva» para que el Juez pueda acordar la relación o contacto con la familia de origen. Si atendemos al tenor literal del precepto, de existir hijos, biológicos o adoptivos de los adoptantes, también se precisaría su consentimiento por formar parte de la familia adoptiva; y de la misma forma, si el adoptante es sólo uno de los cónyuges o de la pareja, no bastaría el asentimiento del cónyuge o pareja como se precisa para la constitución de la adopción (art. 177.2.1 ${ }^{\circ} \mathrm{CC}$ ), sino que se precisaría su consentimiento. No obstante, cabe hacer una interpretación restrictiva y entender que corresponde consentir la adopción abierta sólo a los adoptantes, pues es a ellos a quienes les afecta de manera directa el mantenimiento de la relación o contacto a través de visitas o comunicaciones entre el adoptado y la familia de origen y de la misma forma que no se exige el consentimiento de todos los miembros de la familia del adoptando a la adopción normal, no procede tampoco ahora.»

${ }^{29}$ CALLEJO RODRÍGUEZ, C., «Cuestiones controvertidas en la nueva regulación de la adopción tras la Ley 26/2015, de 28 de julio, de modificación del sistema de protección de la infancia y la adolescencia», Revista Doctrinal Aranzadi CivilMercantil núm. 6/2017. Parte Doctrina. BIB 2017/2018. Editorial Aranzadi, S.A.U., Cizur Menor, 2017 (fecha última consulta 15 de noviembre de 2017). 
Como ya adelantamos, el legislador es consciente de las peculiaridades de este tipo de adopción por lo que hace, o al menos eso parece adivinarse, que los adoptantes y también toda su familia se involucren en el proceso. No pasa desapercibido que a ella aluda en tres de los cuatro párrafos del artículo $178,4^{\circ} \mathrm{CC}$.

A nuestro juicio, sólo los adoptantes son los que han de prestar el consentimiento a la adopción abierta, puesto que únicamente ellos son los que van a formar parte de la relación jurídica adoptiva. Sin embargo, en la práctica, la opinión de otros miembros de la familia será sin duda un criterio muy importante a tener en cuenta tanto en el momento de constitución de este tipo de adopción como en orden al desarrollo de la misma.

Una vez expuestas nuestras consideraciones respecto a los adoptantes, pasamos a continuación a acercarnos a la figura del adoptando.

Por lo que a él se refiere, es unánime el parecer de que esta modalidad de adopción está pensada para aquellos menores de edad que tras unos años en régimen de acogimiento no es conveniente el retorno a sus familias biológicas. Por lo tanto, los acogedores se convertirían en adoptantes y la misma relación que les unía a todos durante el acogimiento será ahora la que presida adopción.

En este sentido, por ejemplo, ALONSO VERGARA, Jefa de la Sección de acogimiento familiar y adopciones de la Diputación Foral de Bizkaia, en su comparecencia en el Senado ${ }^{30}$ ya indicaba, tras anunciar que cada día son más los técnicos que se posicionan a favor de la adopción abierta, que este tipo de adopción «... puede ser beneficiosa para una tipología de niños, como los adolescentes o aquellos que tienen una larga vinculación con su familia extensa y que por determinados motivos no han podido ser adoptados por esa familia o ir en acogimiento con ella...» ${ }^{31}$.

Cuando a las Comunidades Autónomas (en el marco del E.CCAA) se les ha preguntado sobre cuál será la situación más frecuente en la que habrán de encontrarse los menores para que puedan ser adoptados en sistema abierto, la mayoría no ha dudado en mencionar a los niños con un acogimiento previo de larga duración. En el polo opuesto, no se plantean en la actualidad este tipo de adopción ante supues-

${ }^{30}$ BOCG. Senado de 17 de noviembre de 2010 (núm. 545) pág. 9.

${ }^{31}$ El CGPJ también advertía en su informe: «... se trata de una opción que pudiera ser considerada, en principio y para determinados casos, una solución adecuada para el menor, en particular en el caso de adolescentes» (Informe al Anteproyecto de Ley de Protección a la Infancia, cit., pág. 85). 
tos de renuncias hospitalarias, seguramente porque aquellos menores tienen una situación muy diferente a la de los recién nacidos que ni siquiera conocen a sus progenitores $\mathrm{y}$, en su caso, a sus hermanos biológicos.

Una pregunta que en no pocas ocasiones se hacen los adoptantes es cuál puede ser la edad más conveniente para iniciar los contactos con la familia biológica. En opinión de LÓPEZ GALLEGO ${ }^{32}$, «... no hay una respuesta única. Una vez más depende de muchos factores, como la edad de llegada del niño, la existencia de recuerdos de los familiares, etc. Sin embargo se recomienda, en términos generales, iniciar la búsqueda en un momento en que el adoptado alcance una situación de estabilidad y madurez emocional suficiente para poder tomar la decisión de iniciar la búsqueda así como de asumir la información que pueda encontrarse.»

En torno a esta misma cuestión, VILCHES ${ }^{33}$, considera desde una perspectiva psicológica que «... La adopción no podría ser abierta desde un principio. La presencia de la familia biológica dificultaría en mayor medida el proceso de vinculación que se debe llevar a cabo entre el niño y la familia adoptiva, ya que sería un elemento de tensión, que podría provocar un conflicto de lealtades en el niño». Además, añade el mismo autor, "hay que tener en cuenta el proceso madurativo del niño, ya que es necesario a una edad mínima, que garantice una adecuada integración de las dos realidades familiares en la mente del niño para poder pasar a tener un contacto con la familia biológica. Esta edad puede variar en función del desarrollo y nivel de madurez del niño. A partir de los 18 años, siempre que el niño muestre interés, podrían darse encuentros entre la familia biológica y el niño que podrían ser de utilidad en la construcción de su identidad...».

\section{MEDIDAS EN RELACIÓN CON EL PROCEDIMIENTO DE CONSTITUCIÓN}

En relación con el procedimiento, se echa de menos una regulación más detallada. Ya el Consejo General del Poder judicial en su

32 Vid. LÓPEZ-GALLEGO, D., GONZÁLEZ-SOTILLO, R., RUIZ-HUERTA, C., y DE LA CALLE, A. I., «La formación de las familias adoptantes: Buscando sus orígenes». Trabajo Social Hoy, 78, $2^{\circ}$ Cuatr. 2016, (págs. 55-66). doi 10.12960/ TSH.2016.0009, pág. 64.

${ }^{33} \mathrm{http}: / / w w w . l a r a z o n . e s / s o c i e d a d / l a-a d o p c i o n-a b i e r t a-a n t e s-d e-f i n a l-d e-a n o-$ (fecha última consulta: 15 noviembre 2017) 
Informe al Anteproyecto de Ley de Protección a la Infancia ${ }^{34}$, se expresaba en los siguientes términos: «... Si bien consideramos que se ha de ser muy cauteloso y exigirse, en todo caso, informes psicológicos antes de acordar esta clase de adopción y durante su desenvolvimiento, con carácter periódico, teniendo información sobre el desarrollo de las visitas o contactos entre la familia biológica, el menor y la adoptiva.

Por ello, se recomienda una regulación más detallada de la adopción abierta, que incorpore la previsión de que la misma solo se constituirá si fuere conveniente al superior interés del menor, así como la necesidad de los informes psicológicos anteriores y posteriores a su constitución.

Igualmente, debería incluirse la necesidad de remitir al Juez que constituyó la adopción informes periódicos de la Entidad pública sobre el desarrollo de las visitas y propuestas de mantenimiento o modificación. Además, debería regularse el procedimiento para la modificación o finalización de esta adopción, consecuencias de ello y personas legitimadas para solicitarlo, entre las que, obviamente, deberá encontrarse el Ministerio Fiscal, a quien la Entidad pública tendría que remitir también informes de las visitas o contactos.»

A nuestro juicio y aunque se trata de un procedimiento dirigido a facilitar el conocimiento de los orígenes biológicos, quisiéramos llamar la atención sobre la ordenación prevista en el Decreto 169/2015 de 21 de julio aprobado por el Gobierno de la Comunidad Autónoma de Cataluña ${ }^{35}$. El grado de detalle con el que está regulado el mismo puede contribuir a descubrir el camino por el que debe ir la constitución de la adopción abierta.

Se trata de un procedimiento, de duración limitada en el tiempo, en el que se hace mención a la necesidad de contar con acompañamiento técnico (por ejemplo, con apoyo psicológico y social) a fin de conocer las circunstancias en que se produjo la separación, aclarar las posiciones manifestadas por cada una de las personas implicadas y preparar, en su caso, con sesiones previas y posteriores, el encuentro entre ellas (arts. 14 a 16). Asimismo, también se prevé la posibilidad de solicitar un expediente específico de mediación (arts. 17 a 20).

${ }^{34}$ Informe al Anteproyecto de Ley de Protección a la Infancia, cit. en nota siete, págs. 85 y 86.

${ }^{35}$ DOGC núm. 6919 de 23 de Julio de 2015. 


\section{MEDIDAS EN RELACIÓN CON SUS EFECTOS}

El artículo 11 del Convenio Europeo en materia de adopción de menores (revisado), hecho en Estrasburgo el 27 de noviembre de 2008 (ratificado por España el 13 de julio de 2011), está dedicado a los efectos de la adopción y en él se establece lo siguiente: «1. En el momento de la adopción, el menor se convierte en un miembro más de la familia del adoptante o adoptantes a todos los efectos y, con respecto al adoptante o adoptantes y su familia o familias, tendrá los mismos derechos y obligaciones que los de un hijo del adoptante o adoptantes cuya filiación esté legalmente reconocida. El adoptante o adoptantes asumirán la responsabilidad parental con respecto al menor. La adopción pondrá fin al vínculo jurídico existente entre el menor y su padre, madre y familia de origen.

2. No obstante, el cónyuge o la pareja registrada o no del adoptante conservarán sus derechos y obligaciones con respecto al menor adoptado, si el mismo es su propio hijo, a menos que la ley no se oponga a ello.

3. En lo que concierne a la ruptura del vínculo jurídico existente entre el menor y su familia de origen, los Estados Partes podrán prever excepciones para cuestiones tales como el apellido del menor, los impedimentos para el matrimonio o el registro de una pareja de hecho.

4. Los Estados Partes podrán prever disposiciones relativas a otras formas de adopción que tengan efectos más limitados que los indicados en los apartados precedentes del presente artículo.»

Lo que caracteriza a la adopción abierta frente a la adopción tradicional y que obtiene su cobertura legal en el apartado cuarto del artículo 11 que se acaba de transcribir, no es su irrevocabilidad o la extinción de estos vínculos jurídicos, que también acaecen, sino el mantenimiento de los vínculos afectivos a través de un régimen de visitas o comunicaciones entre el menor, los miembros de la familia de origen que se considere y la adoptiva (vid. artículo 178, 4 CC, párrafo primero).

Ésta es su gran particularidad y es que como advierte FERRANDIS TORRES ${ }^{36}$, las nuevas tecnologías favorecen, como nunca antes,

${ }^{36}$ FERRANDIS TORRES, A. $1^{\circ}$ Congreso. Interés Superior del Niño. Acogimiento y Adopción. Adacam (días 19-20 de noviembre de 2013) en http://www.adamcam.org/ documentos/Revista\%20congreso.pdf (Fecha de la última consulta: 15 de noviembre de 2017). 
la comunicación y el intercambio de información en el mundo actual. Los adoptados, gracias a los medios tecnológicos, llegarán a conocer quién es su familia de origen y es lo más probable que intenten contactar con ella. Por este motivo, quizá sea lo más idóneo comenzar a darles información acerca de cual es su historia.

La primera cuestión que debemos abordar es determinar entre qué personas han de tener lugar los contactos.

$\mathrm{Al}$ socaire del artículo $178,4^{\circ} \mathrm{CC}$, deberá ser el Juez quien a propuesta de la Entidad Pública o del Ministerio Fiscal determine qué miembros de la familia de origen sí pueden mantener dichos intercambios de información y cuáles no, teniendo presente que el principio general que inspira esta ordenación - siempre que ello sea posible- es el mantenimiento de la relación entre los hermanos biológicos. El favorecer este tipo de relaciones es uno de los principales objetivos que persigue la adopción abierta como ya se ha encargado de subrayar alguna reciente sentencia judicial (vid. SAP de Córdoba de 18 de noviembre de $2016^{37}$ y la ya citada, SAP de Soria de 15 de diciembre de 2016).

Obviamente, el que el legislador esté pensando en los hermanos biológicos no convierte dichos contactos en una imposición. Por ejemplo y como comenta DE TORRES PEREA ${ }^{38}$, habría que plantear «... si sería posible discriminar las relaciones del menor adoptado con sus hermanos biológicos por considerarse que alguno de ellos supone una influencia negativa para el menor. Si ello justificaría que no se relacionase con ninguno de sus hermanos»

¿Deben circunscribirse los contactos, como expresamente prevé nuestro legislador, con la familia de origen del adoptado? Como expone VÁZQUEZ-PASTOR JIMÉNEZ ${ }^{39}$...»A diferencia de nuestro Derecho, el ordenamiento británico y algunas legislaciones de los Estados norteamericanos, amplían este círculo más allá de los parientes biológicos, extendiéndolo a personas que, sin ser parientes del menor, tienen lazos emocionales significativos con el mismo. Cabría plantear — añade la autora - a la vista de los precedentes anglosajones, sin la norma española sería susceptible de una interpretación extensiva autorizando el juez el contacto a otras personas que no tienen vínculos

${ }^{37}$ El Derecho. Base de Datos (EDJ 2016/251925) AP Córdoba, Sec. 1. a, A 18/11/2016, n. ${ }^{\circ} 483 / 2016$, rec. 761/2016. Fundamento de Derecho segundo (fecha última consulta: 15 de noviembre de 2017).

38 «Problemas actuales relacionados con la adopción» cit. (vid. nota veintiocho), pág. 65.

${ }^{39}$ VÁZQUEZ-PASTOR JIMÉNEZ, L. La nueva figura de la adopción abierta en el Ordenamiento jurídico español, cit. (vid. nota 16), págs. 28 y 29. 
de parentesco con el menor. Dada la excepcionalidad de la nueva figura - concluye- no creemos que quepa dicha interpretación...»

Una vez fijado el ámbito subjetivo, corresponde ahora examinar qué debe entenderse tras la expresión «alguna forma de relación o contacto a través de visitas o comunicaciones». Con buen criterio, en nuestra opinión, el legislador no ha ofrecido especificación alguna por lo que el abanico de posibilidades es casi infinito tanto que, en sí, ni siquiera cabe excluir la posibilidad de mantener una relación caracterizada por la ausencia de encuentros presenciales. Se suele hacer referencia al envío de cartas, intercambio de fotos a través de las agencias de adopción a fin, la utilización de redes sociales, etc. DE LA ROSA CORTINA nos recuerda que ya en los trabajos preparatorios del Anteproyecto de 2011 se decía que «... Junto a la adopción abierta coexiste la adopción semi-abierta: los padres biológicos y los adoptantes se encuentran, conocen sus nombres, pero ningún dato más. Fijan las modalidades de su información recíproca y se comunican siempre a través de los Servicios Sociales» ${ }^{40}$.

En opinión de BERIT HAAS, «... los padres adoptivos deberían estar dispuestos a aceptar formas abiertas de adopción, deberían ser capacitados para imaginar encuentros personales con los padres biológicos, y escribirles cartas ficticias antes de iniciar el procedimiento de adopción. Esto los sensibiliza acerca de las necesidades de los padres biológicos, así como acerca de las del niño adoptado en el futuro» ${ }^{41}$

En lo que concierne a la periodicidad, duración y condiciones de los contactos, serán aspectos que quedarán sometidos a la decisión de la autoridad judicial en interés del adoptando. Su realización, si se estimara oportuno, se llevará a cabo con la intermediación de la Entidad Pública o entidades acreditadas a tal fin.

En este contexto, consideramos que sería muy conveniente tanto la elaboración por parte de las distintas Comunidades Autónomas de formularios que contemplaran el régimen de contactos entre el menor y sus familias (en la actualidad, de acuerdo con el E.CCAA, sólo tres disponen de ellos y cuatro, ya cuentan con proyectos elaborados) así como el intercambio, entre todas ellas, de información respecto a los protocolos de actuación que se han de seguir una vez se determina la

${ }^{40}$ DE LA ROSA CORTINA, J.M. Materiales para interpretar la reforma en la legislación sobre protección jurídica del menor https://www.fiscal.es/fiscal/PA_ WebApp, pág. 51 (fecha última consulta: 15 noviembre 2017).

${ }^{41} \mathrm{Vid}$. http://www.pediatriasocial.es/HtmlRes/Files/ISS_2015_194septiembre_ boletin_ESP.pdf. cit. pág. 6 . 
necesidad de modificar, suspender e, incluso, suprimir el régimen de visitas y comunicaciones ${ }^{42}$.

La intervención de los profesionales en este seguimiento post adoptivo constituirá una de las claves del éxito de su instauración en nuestro país. De hecho, el E.CCAA constata que la mayoría de nuestras Comunidades Autónomas ya han llevado a cabo cursos, charlas, seminarios de formación, etc. específicos sobre adopción abierta para los profesionales. Ojala nos equivoquemos pero habrá que esperar que este mayor contacto entre el adoptado y su familia de origen entre en conflicto con las tradicionales pretensiones de las familias adoptantes. Corresponderá a los responsables de los equipos de vigilar el periodo post adoptivo el hallar los cauces a través de los cuales conciliar los intereses de todas las partes implicadas.

Como sugiere BERIT HAAS, «estos procedimientos abiertos requieren mucha más experticia y mucho más tiempo de trabajo de lo habitual, mayor asesoramiento, más deliberación y reflexión, y por supuesto, mucha más supervisión y orientación después de la adopción ${ }^{43}$. E, igualmente, ACERO ÁLVAREZ (Presidente de la Federació D'Associacions per l'Adopció -FADA-), en su comparecencia ante la Comisión especial del Senado ${ }^{44}$, manifestó que la adopción abierta «debe contar con un pronunciamiento favorable de los equipos profesionales, debe llevarse a cabo un seguimiento adecuado para ver la evolución del menor, toda vez que los padres biológicos deben tener plenamente asumido su situación jurídica respecto del menor, es decir, que a todos los efectos jurídicos ya no son padres del menor.»

Una última cuestión que nos preocupa es averiguar cómo se ha de proceder en los supuestos en que surjan dificultades en la aplicación de los acuerdos alcanzados respecto al régimen de visitas y comunicaciones. Creemos que en la mayoría de los casos, ya provenga la causa del comportamiento de la familia de origen, la adoptivo o, incluso, del propio adoptado que puede ser quien no desee mantener relaciones, por ejemplo, con sus padres biológicos, el recurso a los servicios de

${ }^{42}$ Sobre los interrogantes que plantea la redacción del artículo 178.4 CC en relación con estas competencias del juez en orden a modificar, suspender e incluso suprimir el régimen de contactos puede verse LÓPEZ AZCONA, A. «Luces y sombras del nuevo marco jurídico en materia de acogimiento y adopción de menores: a propósito de la Ley Orgánica 8/2015 y la Ley 26/2015 de modificación del sistema de protección a la infancia y adolescencia» en Boletín del Ministerio de Justicia, Año LXX, núm. 2185, Enero 2016, pág. 73.

${ }^{43} \mathrm{Vid}$. http://www.pediatriasocial.es/HtmlRes/Files/ISS_2015_194septiembre_ boletin_ESP.pdf. cit. pág. 7 .

${ }^{44}$ BOCG. Senado IX Legislatura. Boletín General. Serie I. núm. 545 de 17 de noviembre de 2010, pág. 12 . 
mediación y al apoyo de psicólogos o juristas e, incluso, yendo un paso más allá, a la decisión de modificar, suspender o suprimir los contactos constituirán la respuesta al conflicto planteado. Pero en el concreto caso de unos padres adoptivos que impiden el contacto del menor con su familia de origen ¿son esas soluciones las únicas posibles? No hay que olvidar que se trata de dar cumplimiento a lo acordado en una resolución judicial y que, por supuesto, los perjuicios que se producen con esta contravención no son sólo para la familia de origen sino también, y principalmente, para el menor ya adoptado.

DE TORRES PEREA afirme que en la mayoría de los Estados de EEUU que han aprobado leyes de adopción abierta, lo que está previsto es dejar «... la decisión final en manos de la autoridad judicial que deberá decidir atendiendo en primer lugar al interés del menor ${ }^{45}$. Probablemente no serían descartables, cuando menos y como últimos recursos la imposición de multas coercitivas y, en ocasiones, indemnizaciones por daños y perjuicios a semejanza de lo que en la práctica sucede con los incumplimientos del régimen de visitas fijado en las sentencias de nulidad, separación y divorcio.

¿Se podría llegar incluso a la exclusión de las funciones tuitivas contemplada en el artículo 179 CC? Lo dejamos simplemente apuntado.

La incorporación de forma expresa de la adopción abierta en el Código civil puede estar haciendo que sea más conocida socialmente, gracias sobre todo a los medios de comunicación e, incluso, más tenida en cuenta a nivel administrativo o judicial. Sin embargo, en nuestra opinión, no debemos ver en ella la panacea que va a permitir que aquellos menores a los que hacía mención nuestro legislador, especialmente los más mayores, cuya adopción presenta más dificultades, sean adoptados.

En cierto modo, permítasenos el símil, la incorporación de esta «nueva» figura jurídica nos recuerda, mutatis mutandis, al fenómeno que en su día trajo consigo la admisión expresa de otra, también calificada —cuando no lo era- de «nueva» institución jurídica: la guarda y custodia compartida.

Desde bastantes años antes de la entrada en vigor de la Ley $15 / 2005$, de 8 de junio, conocida como la del divorcio exprés, nuestros Tribunales ya recogían en sus sentencias la guarda y custodia compartida, pero es que constituyendo sin duda el modelo de guarda más

${ }^{45}$ DE TORRES PEREA, J.M., «Problemas actuales relacionados con la adopción» en Revista de Derecho de Familia, núm. 72 (julio-septiembre 2016), pág. 64 
aconsejable, no por el hecho de serlo se podía, ni se puede en la actualidad, imponer cuando su implantación no es lo más adecuado para el interés de los hijos. La jurisprudencia nos demuestra cada día que junto a una serie de factores favorables en la situación familiar debe darse una implicación y un alto grado de colaboración entre los progenitores. Sólo así es viable su establecimiento. Pues bien, a nuestro juicio, lo mismo cabe afirmar de la adopción abierta. Tampoco se puede imponer. Mucho habrán de poner de su parte tanto el menor como sus familias biológicas y adoptante, para que el mantenimiento de esos contactos redunde en su bienestar. Dicho todo lo cual, bastará con que algunos menores, un solo menor, logre alcanzar una mayor estabilidad familiar y personal para que su reconocimiento en el Código civil, encuentre sobrada justificación.

En todo caso, siguiendo la opinión de FERRANDIS TORRES (Pedagogo Social. Jefe del Área de adopciones del IMFM) «por tranquilizar a quienes perciben signos de alarma en esta innovación, en el caso español la adopción abierta vendrá, más que a debilitar la adopción, a consolidar el acogimiento permanente» ${ }^{46}$.

\section{CONCLUSIONES}

PRIMERA: Nuestro sistema de protección a la infancia y a la adolescencia se ha visto envuelto recientemente en una importante y extensa reforma. La institución de la adopción no ha sido una excepción, si bien es cierto que las modificaciones realizadas lo han sido hacia una dirección bastante distinta a las emprendidas anteriormente.

El interés del menor, en tanto que principio que debe ser valorado como primordial en todas las situaciones en las que se encuentre, ha traído como consecuencia el que su vida y desarrollo personal deban tener lugar en un entorno familiar adecuado, preferentemente, en su familia de origen. Cuando esta opción no es la más idónea para él y sí, la de la adopción, el derecho - del que es titular- a conocer sus orígenes ha de alcanzar toda su significación. El final de su búsqueda no puede quedar limitado al ámbito biológico (vínculo genético con sus ascendientes) o socio-familiar (el conocimiento de su historia personal-familiar) sino que debe ir más allá y, además, prolongarse en el tiempo junto a aquellos que siempre constituirán su familia de origen.

${ }^{46}$ FERRANDIS TORRES, A., $1^{\circ}$ Congreso. Interés Superior del Niño. Acogimiento y Adopción. cit.

(C) UNED. Revista de Derecho UNED, núm. 22, 2018 
SEGUNDA: La institución de la adopción, en su modalidad de abierta, es decir aquélla que admite — cuando el interés del adoptado así lo aconseje- el mantenimiento de una cierta forma de contacto entre el menor, los miembros de su familia de origen y la familia adoptiva, se ha erigido por nuestro el legislador estatal como el instrumento dirigido, de una parte, a conciliar los distintos intereses en juego (el del niño así como sus dos familias) y, de otra, a facilitar la reducción del número de menores de edad que se encuentran en situación de adoptabilidad nacional.

TERCERA: Han transcurrido más de dos años desde la entrada en vigor de la Ley $26 / 2015$, de 28 de julio y la pregunta que planteamos en el presente estudio gira sobre el establecimiento real de la adopción abierta en nuestro país o, quizá debiéramos decir más correctamente, en las distintas Comunidades Autónomas pues son ellas las competentes por razón de la materia para su puesta en marcha.

CUARTA: Aunque ha sido frecuente calificar como de "gran novedad» la incorporación de la adopción abierta, la verdad es que en varias de nuestras Comunidades Autónomas ya se estaban dando supuestos de esta modalidad de adopción antes de la entrada en vigor de la Ley. Por ejemplo en las de Andalucía, Cataluña, Galicia y País Vasco.

QUINTA: Para la elaboración de nuestro trabajo nos hemos servido del estudio de las contestaciones que los distintos responsables de nuestras Comunidades Autónomas ofrecieron a un cuestionario en torno a la instauración en sus territorios de la adopción abierta (en adelante E.CCAA). Las mismas fueron expuestas durante los días 21 y 22 de junio en unas jornadas que con el título «Rompiendo moldes: adopciones especiales y adopciones abiertas en pro del interés superior del niño» se desarrollaron en la Universidad Pontificia Comillas de Madrid. Esta actividad de desarrolló y ha sido parcialmente financiada por el Ministerio de Economía y Competitividad en el marco del proyecto de investigación «La apertura de la comunicación sobre adopción en España: en camino hacia la adopción abierta» y por la Universidad Pontificia Comillas CEIR ARISTOS Campus Mundus en el marco del proyecto de investigación «Desafíos actuales de la adopción en España: Necesidades y derechos de los menores en acogimientos y adopción».

SEXTA: El escaso número actual de adopciones abiertas existentes en España, tiene su explicación en una diversidad de motivos. Entre otros, de la información obtenida del E.CCAA, no hay que descartar la 
falta de recursos suficientes, materiales y humanos dirigidos hacia su establecimiento. En la mayoría de nuestras Comunidades Autónomas sí que se han actualizado los contenidos de las charlas y sesiones informativas que se imparten tanto a los posibles adoptantes como a las familias que tienen en acogida a algún menor. No obstante, en más de la mitad de ellas todavía no se han terminado de adaptar los folletos informativos o las páginas Webs ni tampoco se han adaptado los cursos de formación ni los modelos de ofrecimiento para la adopción.

SÉPTIMA: ¿Qué medidas se pueden establecer para impulsar el establecimiento de la adopción abierta? sitos:

En primer lugar, por lo que concierne a sus presupuestos o requi-

Comenzando por las personas que quieren ser adoptantes, el legislador ha exigido como única especialidad el que en su declaración de idoneidad ha de hacerse constar expresamente si aceptarían a un menor que fuese a mantener relaciones (visitas, comunicaciones) con la familia de origen.

Preguntadas las Comunidades Autónomas acerca de si se había procedido a adaptar el tradicional concepto de idoneidad a esta nueva modalidad de adopción, si bien es cierto que aún se está pendiente - en la mayoría de las ellas- de dar una nueva configuración a los materiales (formularios), sí que se está teniendo muy en cuenta a nivel individual en los procesos adoptivos. Asimismo, la mayoría de ellas han adaptado los estudios psicosociales teniendo en cuenta la posibilidad de este tipo de adopción y se han fijado (o se encuentran en desarrollo) los criterios específicos para valorar la idoneidad de los adoptantes en estos casos.

A nuestro juicio sería oportuno, especialmente en estos momentos incipientes en los que se encuentra la adopción abierta, de una parte, que entre las distintas Comunidades Autónomas se diera un mayor grado de colaboración en lo relativo al tratamiento del requisito de la idoneidad con el propósito de alcanzar un tratamiento unificado, es decir, con independencia del territorio en el que nos encontremos. Y, de otra, la creación de registros específicos de familias solicitantes de adopciones abiertas.

En lo que atañe a los adoptandos, cuando a las Comunidades Autónomas (en el marco del E.CCAA) se les ha preguntado sobre cuál será la situación más frecuente en la que habrán de encontrarse los menores para que puedan ser adoptados en sistema abierto, la mayoría ha mencionado a los niños con un acogimiento previo de larga duración. 
En segundo lugar, en lo que respecta a las medidas que tienen que ver con el procedimiento de constitución, ante la ausencia de una regulación detallada y aunque se trata de un procedimiento dirigido a facilitar el conocimiento de los orígenes biológicos, quisiéramos llamar la atención sobre la ordenación prevista en el Decreto 169/2015 de 21 de julio aprobado por el Gobierno de la Comunidad Autónoma de Cataluña. El grado de concreción con el que está regulado el mismo puede contribuir a emprender el camino por el que debe ir el procedimiento de la constitución de la adopción abierta.

Y en tercer y último lugar, por lo que atañe a los efectos de la misma, estimamos muy conveniente tanto la elaboración por parte de las distintas Comunidades Autónomas de formularios que contemplen el régimen de contactos entre el menor y sus familias (en la actualidad, de acuerdo con el E.CCAA, tres disponen de ellos y cuatro, cuentan con proyectos elaborados) así como el intercambio, entre todas ellas, de información respecto a los protocolos de actuación que se han de seguir una vez se determina la necesidad de modificar, suspender e, incluso, suprimir el régimen de visitas y comunicaciones.

La intervención de los profesionales en este seguimiento post adoptivo constituirá una de las claves del éxito de esta nueva modalidad de adopción.

En los supuestos en que surjan dificultades en la aplicación de los acuerdos alcanzados respecto al régimen de visitas y comunicaciones, creemos que en la mayoría de los casos, ya provenga la causa del comportamiento de la familia de origen, la adoptivo o, incluso, del propio adoptado (que puede ser quien no desee mantener relaciones, por ejemplo, con sus padres biológicos) el recurso a los servicios de mediación y al apoyo de psicólogos o juristas constituirán la respuesta al conflicto planteado.

\section{BIBLIOGRAFÍA CITADA}

Acero Álvarez, F.: intervención en la Comisión Especial de Estudio de la problemática de la adopción nacional y otros temas afines (Boletín Oficial de las Cortes Generales. Senado. IX Legislatura. Serie I. Boletín General de de 17 de noviembre de 2010, núm. 545).

Adroher Biosca, S.: declaraciones al Diario el País (https://política. elpaís.com/politica/2014/09/30/actualidad. Fecha de la última consulta: 15 noviembre de 2017) 
Alonso Vergara, C.: intervención en la Comisión Especial de Estudio de la problemática de la adopción nacional y otros temas afines (Boletín Oficial de las Cortes Generales. Senado. IX Legislatura. Serie I. Boletín General de de 17 de noviembre de 2010, núm. 545)

ANGUita Ríos, R.M. ${ }^{\mathrm{a}}$. « "La adopción abierta. Un paso más en el derecho a la identidad biológica del adoptado", Revista Doctrinal Aranzadi Civil-Mercantil, núm. 11/2016. Parte Doctrina. Editorial Aranzadi, S.A.U., Cizur Menor, 2016 (BIB 2016/85672). Fecha de la última consulta 15 de noviembre de 2017.

BERIT HASs: (http://www.pediatriasocial.es (HtmlRes(Files/ ISS_2015_194 septiembre_boletín_ESP. pdf)

CALlejo Rodríguez, C., "Cuestiones controvertidas en la nueva regulación de la adopción tras la Ley 26/2015, de 28 de julio, de modificación del sistema de protección de la infancia y la adolescencia», Revista Doctrinal Aranzadi Civil-Mercantil núm. 6/2017. Parte Doctrina. BIB 2017/2018. Editorial Aranzadi, S.A.U., Cizur Menor, 2017 (fecha de la última consulta 15 de noviembre de 2017).

CÉCILE JEANNIN: EL NUEVO RÉGIMEN JURÍDICO DEL MENOR. LA REFORMA LEGISLATIVA DE 2015 (Directora: MaYor Del Hoyo, M. ${ }^{\text {. }}$ V.) Thomson Reuters Aranzadi, Pamplona, 2017.

Consejo General del Poder Judicial: Informe al Anteproyecto de Ley de Protección a la Infancia de 30 de septiembre de 2014 en www. poderjudicial.es (fecha de la última consulta: 15 de noviembre de 2017)

De la Rosa Cortina, J.M. Materiales para interpretar la reforma en la legislación sobre protección jurídica del menor (https://www.fiscal. es/fiscal/PA_WebApp. Fecha de la última consulta: 15 noviembre 2017).

De Torres Perea, J.M., «Problemas actuales relacionados con la adopción» en Revista de Derecho de Familia, núm. 72 (julio-septiembre 2016).

Ferrandis TorRes, A.: $1^{\circ}$ Congreso. Interés Superior del Niño. Acogimiento y Adopción. Adacam celebrado los días 19 y 20 de noviembre de 2013 (http://www.adamcam.org/documentos/Revista\%20 congreso.pdf. Fecha de la última consulta: 15 de noviembre de 2017).

Fiscalía General del Estado. Consejo Fiscal: Informe al Anteproyecto de Ley de Protección a la Infancia de 11 de julio de 2014 (https//www. fiscal.es. Fecha de la última consulta: 15 de noviembre de 2017). 
KATZ JILL: www.pediatriasocial.es/HtmlRes/Files/ISS_2015_194septiembre_ boletin_ESP.pdf. (fecha de la última consulta: 15 noviembre 2017).

LÓPEz AzConA, A. «Luces y sombras del nuevo marco jurídico en materia de acogimiento y adopción de menores: a propósito de la Ley Orgánica 8/2015 y la Ley 26/2015 de modificación del sistema de protección a la infancia y adolescencia» en Boletín del Ministerio de Justicia, Año LXX, núm. 2185, Enero 2016.

LóPez-Gallego, D., González-Sotillo, R., Ruiz-Huerta, C., y DE LA CALLE, A. I.: «La formación de las familias adoptantes: Buscando sus orígenes». Trabajo Social Hoy, 78, $2^{\circ}$ Cuatr. 2016. doi 10.12960/ TSH.2016.0009, pág. 64.

Martínez de Aguirre Aldaz: El nuevo régimen jurídico del menor. La reforma legislativa de 2015 (Directora: Mayor del Hoyo, M. ${ }^{a}$. V.) Thomson Reuters Aranzadi, Pamplona, 2017.

Múgica Flores, J.: intervención en la Comisión Especial de Estudio de la problemática de la adopción nacional y otros temas afines (Boletín Oficial de las Cortes Generales. Senado. IX Legislatura. Serie I. Boletín General de de 17 de noviembre de 2010, núm. 545).

Palacios GonzÁlez, J.: intervención en la Comisión Especial de Estudio de la problemática de la adopción nacional y otros temas afines (Boletín Oficial de las Cortes Generales. Senado. IX Legislatura. Serie I. Boletín General de de 17 de noviembre de 2010, núm. 545).

PAVÓN PÉREZ, J. A.: declaraciones al periódico de Extremadura (http:// www.elperiodicoextremadura.com/noticias/opinion/adopcionabierta-extremadura. Fecha de la última consulta: 15 de noviembre de 2017).

RuIz-Rico RuIZ-Moron, J. «Últimas reformas de las instituciones privadas de protección de menores y la filiación por la Ley 26/2015, de modificación del sistema de protección a la infancia y la adolescencia» en Revista Doctrinal Aranzadi Civil-Mercantil, núm. 3/2016, parte Doctrina, Editorial Aranzadi, S.A.U., Cizur Menor, 2016 (BIB2016/862). Fecha de la última consulta: 15 noviembre 2017.

SABATER BAYLE, E.: «la adopción abierta en el derecho español» en Actualidad Jurídica Iberoamericana, IDIBE, núm. 4 ter, julio 2016.

VÁzouez-PAstor JiméNEz, L.: «La nueva figura de la adopción abierta en el ordenamiento jurídico español» en Actualidad civil, núm. 4, abril de 2017.

Vilches Alonso, J.: declaraciones al Diario La Razón (http://www.larazon.es/sociedad/la-adopcion-abierta-antes-de-final-de-ano-. Fecha de la última consulta: 15 noviembre 2017) 